\title{
Video Article \\ Genome-wide Analysis of Aminoacylation (Charging) Levels of tRNA Using Microarrays
}

\author{
John Zaborske ${ }^{1}$, Tao Pan ${ }^{1}$ \\ ${ }^{1}$ Department of Biochemistry and Molecular Biology, University of Chicago \\ Correspondence to: Tao Pan at taopan@uchicago.edu \\ URL: https://www.jove.com/video/2007 \\ DOI: doi:10.3791/2007
}

Keywords: Cellular Biology, Issue 40, tRNA, aminoacylation, charging, microarray, S. cerevisiae

Date Published: 6/18/2010

Citation: Zaborske, J., Pan, T. Genome-wide Analysis of Aminoacylation (Charging) Levels of tRNA Using Microarrays. J. Vis. Exp. (40), e2007, doi:10.3791/2007 (2010).

\section{Abstract}

tRNA aminoacylation, or charging, levels can rapidly change within a cell in response to the environment[1]. Changes in tRNA charging levels in both prokaryotic and eukaryotic cells lead to translational regulation which is a major cellular mechanism of stress response. Familiar examples are the stringent response in $E$. coli and the Gcn2 stress response pathway in yeast ([2-6]). Recent work in $E$. coli and $S$. cerevisiae have shown that tRNA charging patterns are highly dynamic and depends on the type of stress experienced by cells $[1,6,7]$. The highly dynamic, variable nature of tRNA charging makes it essential to determine changes in tRNA charging levels at the genomic scale, in order to fully elucidate cellular response to environmental variations. In this review we present a method for simultaneously measuring the relative charging levels of all tRNAs in $S$. cerevisiae . While the protocol presented here is for yeast, this protocol has been successfully applied for determining relative charging levels in a wide variety of organisms including $E$. coli and human cell cultures[7, 8].

\section{Video Link}

The video component of this article can be found at https://www.jove.com/video/2007/

\section{Protocol}

\section{Part 1: Isolation of total charged tRNA}

1. Pellet cells in a tabletop centrifuge at $2000 \mathrm{RFC}$ for 5 minutes. The equivalent of $1 \mathrm{OD}_{600}$ of cells should produce at least $1 \mu \mathrm{g}$ of total RNA and a minimum of $30 \mu \mathrm{g}$ is recommended for the procedure.

2. Resuspend cells in lysis buffer solution consisting of $0.3 \mathrm{M}$ buffered $\mathrm{Na}^{+}$-acetate $(\mathrm{pH} 4.5)$ and $10 \mathrm{mM}$ EDTA. Vortex with an equal volume of $\mathrm{Na}^{+}$-acetate-saturated phenol/chloroform $(\mathrm{pH} 4.5)$ three times each for $30 \mathrm{~s}$. Be sure to always keep samples on ice between vortexing. Buffered acetate can be prepared from $\mathrm{NaOAC}$ and $\mathrm{HOAc}$ while acetate saturated phenol/chloroform can be prepared by mixing 1 part $5 \mathrm{M}$ buffered acetate $(\mathrm{pH} 4.5)$ with 9 parts phenol/chloroform.

Note: total RNA isolation is carried out under mildly acidic conditions and on ice to avoid deacylation of charged tRNA.

3. Centrifuge at $18,600 \mathrm{RFC}$ for 15 minutes at $4^{\circ} \mathrm{C}$. Remove the aqueous layer and perform another acetate-saturated phenol/chloroform extraction.

4. After the second extraction precipitate the RNA by adding $2.7 x$ volumes of ethanol and centrifuging at 18,600 RFC for 30 minutes at $4{ }^{\circ} \mathrm{C}$.

5. Resuspend RNA pellets in lysis buffer solution and then precipitate with ethanol a second time.

6. Finally, resuspend the RNA in a solution containing $10 \mathrm{mM}$ buffered acetate $(\mathrm{pH} \mathrm{4.5)}$ and $1 \mathrm{mM}$ EDTA for subsequent treatment. The sample can be stably stored at $-80^{\circ} \mathrm{C}$ for about two weeks. Longer storage is not recommended as some charged tRNA will start to deacylate.

\section{Part 2: Preparation of tRNA Standards}

1. Heat $E$. coli tRNA standards at $10.5 \mu \mathrm{M}$ to $85^{\circ} \mathrm{C}$ in $45 \mathrm{mM}$ Tris- $\mathrm{Cl} \mathrm{pH} 7.5$ for 2 minutes. Take the tube out and leave at room temperature for 3 minutes.

2. Add $\mathrm{MgCl}_{2}$ to a final concentration of $20 \mathrm{mM}$ and incubate at $37^{\circ} \mathrm{C}$ for 5 minutes.

3. Add the synthetase reaction mix so the final reaction contains $5 \mu \mathrm{M}$ tRNA, $60 \mathrm{mM}$ Tris- $\mathrm{HCl}(\mathrm{pH} 7.5), 12.5 \mathrm{mM} \mathrm{MgCl}, 10 \mathrm{mM} \mathrm{KCl}, 3 \mathrm{mM}$ dithiothreitol, $1.5 \mathrm{mM}$ ATP, $1 \mathrm{mM}$ spermine, $1 \mathrm{mM}$ of the respective amino acid, and $4.2 \mathrm{units} / \mu \mathrm{l} E$. coli aminoacyl-tRNA synthetase mix. Incubate at $37^{\circ} \mathrm{C}$ for 15 minutes.

4. Add an equal volume of $0.5 \mathrm{M}$ buffered acetate $(\mathrm{pH} \mathrm{4.5)}$ and extract with acetate-saturated phenol/CHCl 3 at $\mathrm{pH} 4.5$.

5. Precipitate the tRNA standards with $2.7 x$ volumes of ethanol and centrifuging at $18,600 \mathrm{RFC}$ for 30 minutes at $4^{\circ} \mathrm{C}$.

6. Resuspend the standards in $50 \mathrm{mM}$ buffered acetate $\left(\mathrm{pH} \mathrm{4.5)}\right.$ with $1 \mathrm{mM}$ EDTA and store at $-80^{\circ} \mathrm{C}$ for up to one month. 


\section{Part 3: Сy3/Cy5 labeling of tRNA}

1. For the charged tRNA sample incubate total RNA at a concentration of $0.1 \mu \mathrm{g} / \mu \mathrm{l}$ with $0.066 \mu \mathrm{M}$ each E. coli tRNA standards (i.e. $0.67 \mathrm{pmole}$ each standard per $\mu \mathrm{g}$ total RNA) and $100 \mathrm{mM}$ buffered acetate $(\mathrm{pH} 4.5)$ in the presence of $50 \mathrm{mM}$ NalO4 for 30 minutes at room temperature. For the control total tRNA sample use $50 \mathrm{mM} \mathrm{NaCl}$ in place of NalO4. Remember to dilute the RNA only with buffered solutions to preserve charging.

2. To quench the reaction add glucose to $100 \mathrm{mM}$ and incubate at room temperature for 5 minutes.

3. In order to remove any remaining NalO4 from the sample perform a buffer exchange using a $\mathrm{G} 25$ spin column. For best results equilibrate the column first by running $200 \mathrm{mM}$ buffered acetate buffer $(\mathrm{pH} \mathrm{4.5)}$ through it prior to applying your sample.

4. Precipitate the sample by adding buffered acetate $(\mathrm{pH} 4.5)$ to a final concentration of $133 \mathrm{mM}$ and $\mathrm{NaCl}$ to a final concentration of $66 \mathrm{mM}$ and $2.7 x$ volumes of ethanol. Occasionally a second precipitation may be needed for the oxidized samples. This is necessary only if the pellet looks significantly different than the control pellet of the same sample. For example a significantly bigger or more diffuse pellet. If a second ethanol precipitation is required resuspend pellet in $50 \mathrm{mM}$ acetate buffer $\mathrm{pH} 4.5$ and $200 \mathrm{mM} \mathrm{NaCl}$ before the addition of ethanol.

5. For deacylation the tRNA samples are resuspended in $50 \mathrm{mM} \mathrm{Tris}-\mathrm{HCl}(\mathrm{pH} 9)$ and incubated at $37^{\circ} \mathrm{C}$ for 30 min. The reaction is neutralized by the addition of an equal volume of $50 \mathrm{mM}$ buffered acetate $(\mathrm{pH} 4.5)$ and $100 \mathrm{mM} \mathrm{NaCl}$. Precipitate with $2.7 x$ volumes of ethanol. After precipitation, RNA is resuspended in water at $\sim 1 \mu \mathrm{g} / \mu \mathrm{l}$. Both the control and oxidized samples should be run on agarose gels to check RNA quality.

6. To attach fluorescent oligo tags onto the tRNA $0.1 \mu \mathrm{g} / \mu$ l deacylated RNA is incubated in $1 \mathrm{x}$ ligase buffer, $15 \%$ DMSO, $4 \mu \mathrm{M} \mathrm{Cy3-} \mathrm{or} \mathrm{Cy5-}$ containing oligonucleotides, 0.5 units/ $\mu \mathrm{l} \mathrm{T4} \mathrm{DNA} \mathrm{ligase,} \mathrm{and} \mathrm{yeast} \mathrm{exo-phosphatase}(5,000 \mathrm{units} / \mu \mathrm{l})$ at $16^{\circ} \mathrm{C}$ overnight (over $\left.16 \mathrm{~h}\right)$. The exophosphatase is necessary only for samples obtained from yeast and can be omitted if this protocol is used for $E$. coli or human samples.

7. After ligation samples are mixed with 4 volumes of $50 \mathrm{mM} \mathrm{KOAc}(\mathrm{pH} 7), 200 \mathrm{mM} \mathrm{KCl}$, and then extracted with an equal volume of phenol/ chloroform. Following extraction of the aqueous phase, RNA preparations are precipitated with ethanol and resuspended in water to approximately $0.1 \mu \mathrm{g} / \mu \mathrm{l}$.

8. Ligation efficiency can be assessed by running $5-10 \%$ of the samples on $12 \%$ polyacrylamide gels containing $7 \mathrm{M}$ urea and visualized with a fluorescent gel scanner. This PAGE analysis is also useful to determine the amount of oxidized and control samples needed for microarray hybridization. A good ligation result should show $\sim 10 \%$ or more of the Cy3/Cy5 containing oligonucleotide being ligated to the tRNA. For samples with good labeling efficiency, 0.1-0.5 $\mu \mathrm{g}$ total RNA per sample is used for array hybridization.

\section{Part 4: Hybridization and Analysis of the Microarray}

1. Prior to hybridization microarray slides are boiled in distilled water for 1-2 minutes to remove unbound oligonucleotides.

2. Сy3/Cy5 labeled samples are combined with $140 \mu \mathrm{l}$ of hybridization buffer and salmon sperm DNA to a final concentration of $140 \mu \mathrm{g} / \mathrm{ml}$ and poly(A) to a final concentration of $70 \mu \mathrm{g} / \mathrm{ml}$.

3. A hybridization program, (table 1), is run on an automatic array hybridizer. For tRNA work, it is highly recommended that an automatic hybridization machine be used since manual hybridization produces high background.

4. After the program is complete manually wash the slides with Wash 3 solution at least twice by gently shaking in a $50 \mathrm{ml}$ conical tube for $3-5$ minutes.

5. Slides can be dried by centrifuging at a low speed, less than 200 RFC, for 5-10 minutes. It is important to keep the slides out of the light since exposure to light will bleach the fluorophores.

6. After the slides are dried they should be scanned immediately for optimal results; if necessary they can be saved for several days in a dry dark place at room temperature. Slides can be scanned 2-3 times without noticeable degradation in image quality.

\section{Part 5: Representative Results}

When isolated properly the total RNA sample should produce a very clean spectrum with an $\mathrm{OD}_{260}: \mathrm{OD}_{280}$ ratio near 2 . There should be no detectable protein or phenol contamination. When run on $1 \%$ agarose gels, a strong tRNA band should be observed with other possible nucleic acid bands varying between organisms. After oxidation a clean tRNA band should be observed. If a sample is noticeably weaker than other samples or smearing is observed, samples should not be used for microarrays. Microarrays should have very low background which is an order of magnitude lower than the weakest tRNA probe. High background is usually due to problems during the washing steps. This can usually be fixed by preparing fresh wash solutions and thoroughly washing all equipment and tubing to remove residual and precipitated SDS.

\begin{tabular}{|l|l|}
\hline Step & Details \\
\hline O-ring conditioning & $75^{\circ} \mathrm{C}, 2 \mathrm{~min}$ \\
\hline Introduce sample & $60^{\circ} \mathrm{C}$ \\
\hline Denature Sample & $90^{\circ} \mathrm{C}, 5 \mathrm{~min}$ \\
\hline Hybridization & $60^{\circ} \mathrm{C}, 16 \mathrm{~h}$ \\
\hline Wash 1 & $50^{\circ} \mathrm{C}$, flow $10 \mathrm{~s}$ hold $20 \mathrm{~s}$ \\
\hline Wash 2 & $42^{\circ} \mathrm{C}$, flow 10 s hold $20 \mathrm{~s}$ \\
\hline Wash 3 & $42^{\circ} \mathrm{C}$, flow $10 \mathrm{~s}$ hold $20 \mathrm{~s}$ \\
\hline
\end{tabular}

Table 1: Hybridization protocol 


\section{Discussion}

We present a method for simultaneously determining the relative charging levels of all tRNAs at the genomic scale. The protocol presented here has been optimized for $S$. cerevisiae, and it has also been successfully used to measure tRNA charging profiles in $E$. coli and human cell cultures. It can be modified to accommodate any organism with known genome sequences (allowing for annotation of all tRNA genes) as long as total charged tRNA can be obtained.

\section{Disclosures}

No conflicts of interest declared.

\section{Acknowledgements}

The yeast work in the Pan lab was funded by a grant from Ajinomoto, Inc. Japan and National Institutes of Health Training Grant T32GM007183-33. We thank Dr. Ronald Wek at the Indiana University School of Medicine for long-term collaboration on the yeast projects. We also thank Dr. Kimberly Dittmar for developing the tRNA charging microarray method.

\section{References}

1. Zaborske, J.M., et al., Genome-wide analysis of tRNA charging and activation of the elF2 kinase Gcn2p. J Biol Chem, 284(37): p. 25254-67 (2009).

2. Wek, S.A., S. Zhu, and R.C. Wek, The histidyl-tRNA synthetase-related sequence in the elF-2 alpha protein kinase GCN2 interacts with tRNA and is required for activation in response to starvation for different amino acids. p. 4497-4506 (1995).

3. Hinnebusch, A.G., Translational Regulation of GCN4 and the General Amino Acid Control of Yeast. Annual Review of Microbiology, 59(1): p. 407-450 (2005).

4. Braeken, K., et al., New horizons for (p)ppGpp in bacterial and plant physiology. Trends in Microbiology, 14(1): p. 45-54 (2006).

5. Dong, J., et al., Uncharged tRNA Activates GCN2 by Displacing the Protein Kinase Moiety from a Bipartite tRNA-Binding Domain. Molecular Cell, 6(2): p. 269-279 (2000).

6. Cashel M., et al., The Stringent Response, in Escherichia coli and Salmonella: cellular and molecular biology, N. F.C., Editor, ASM Press: Washington D.Cl. p. 1458-1496 (1996).

7. Dittmar, K.A., et al., Selective charging of tRNA isoacceptors induced by amino-acid starvation. EMBO Rep, 6(2): p. 151-7 (2005)

8. Zhou, Y., et al., High levels of tRNA abundance and alteration of tRNA charging by bortezomib in multiple myeloma. Biochem Biophys Res Commun, 385(2): p. 160-4 (2009). 